
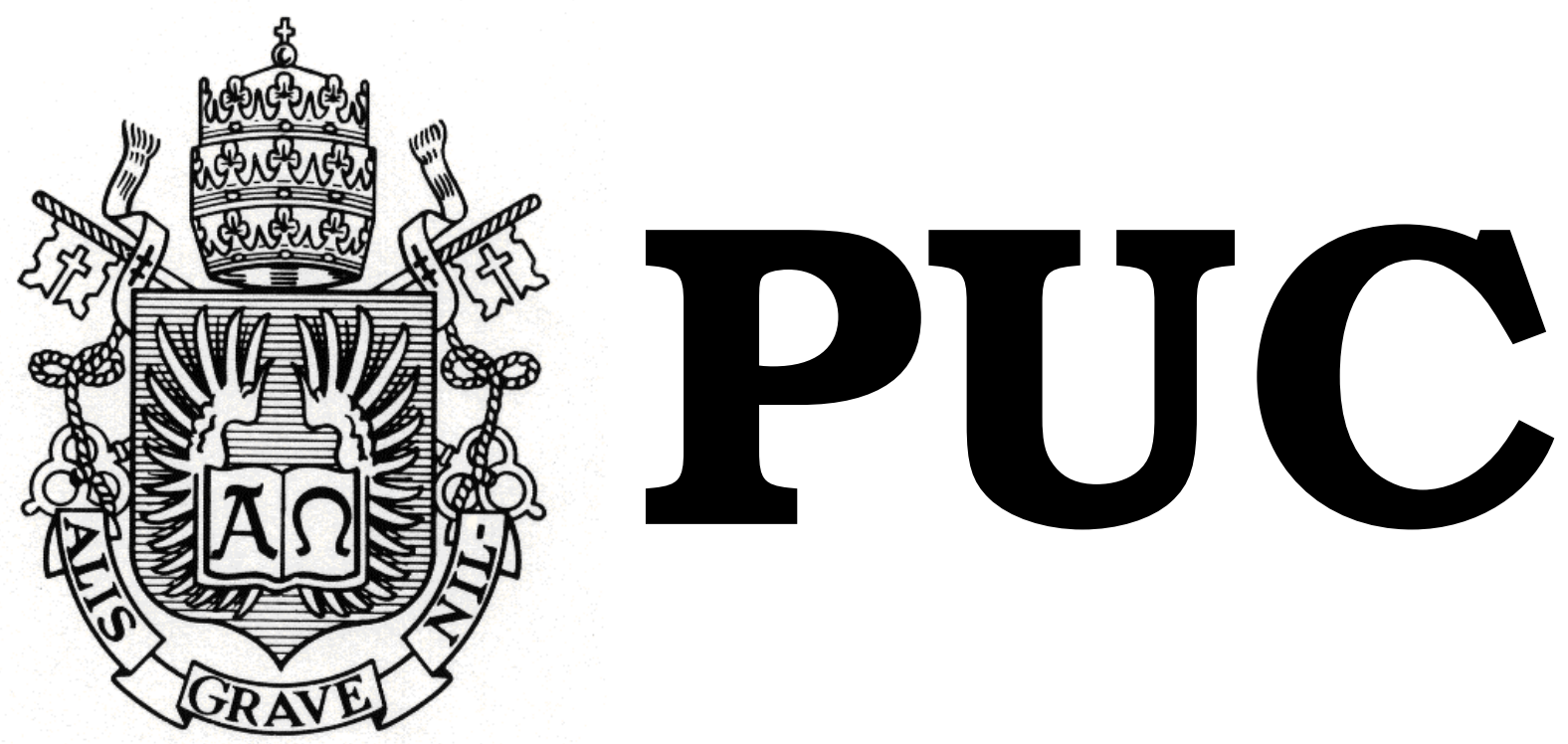

DEPARTAMENTO DE DIREITO

\title{
EXCLUSÃO DO SÓCIO NA SOCIEDADE \\ LIMITADA
}

por

RAFAEL SANTIAGO FIRMO

ORIENTADOR(A): FRANCISCO ANTUNES MACIEL MÜSSNICH

2011.2

PONTIFÍCIA UNIVERSIDADE CATÓLICA DO RIO DE JANEIRO

RUA MARQUÊS DE SÃO VICENTE, 225 - CEP 22453-900

RIO DE JANEIRO - BRASIL 


\title{
EXCLUSÃO DO SÓCIO NA SOCIEDADE LIMITADA
}

\author{
Por \\ RAFAEL SANTIAGO FIRMO
}

Monografia apresentada ao Departamento de Direito da Pontifícia Universidade Católica do Rio de Janeiro (PUC-Rio) para a obtenção do Título de Bacharel em Direito.

Orientador(a):

Francisco Antunes Maciel Müssnich 
A meus avós, Cleofas e Edy, pelo longo convívio e exemplo de vida, A meus avós, Sergio e Solange, minhas maiores saudades. 


\section{AGRADECIMENTOS}

Para concluir esse trabalho, certamente contei com o apoio de pessoas fundamentais que sempre transmitiram a confiança necessária de que o trabalho, uma vez desenvolvido de forma séria e dedicada, traria resultado satisfatório.

Primeiramente agradeço a meus pais, Nise e Sergio, pois são os maiores motivos de meu ingresso na vida jurídica. Se escrevo sobre um tema ligado ao direito empresarial, é só porque contei com a aprovação de vocês da minha área de atuação.

Também é devido o agradecimento aos meus irmãos, avós e demais parentes e amigos, que nunca demonstraram dúvida sobre meu potencial de concluir satisfatoriamente o curso de Direito numa faculdade de destaque.

Ainda, agradeço ao meu orientador, Professor Francisco Mussnich, pelo apoio e confiança em mim depositados. Igualmente grato às advogadas Patrícia Sabino, Isabel Pumar e Marina Croce, pelo conhecimento que me transmitiram nos últimos 12 meses e pelo incentivo a frequentes estudos, que acabaram por fazer me deparar com o tema abordado no presente trabalho.

Por último, porém não menos importante, agradeço à minha namorada Cammila, pelo apoio incondicional que sempre dedicou-me, com carinho e crença de que não só este trabalho, mas minha vida profissional como um todo seriam bem sucedidos. 


\section{RESUMO}

Esta monografia foi desenvolvida com o intuito de demonstrar a possibilidade de uma padronização do instituto da exclusão do sócio que hoje encontra amparo do Novo Código Civil, com o objetivo de esclarecer os casos nos quais os sócios pode ser excluído.

Para tanto, foram analisadas doutrina e Jurisprudência, que embora divergentes capacitaram um delineamento organizado, de modo a ensejar a exposição do procedimento da exclusão de sócios cada vez mais claro, aumentando a segurança jurídica acerca do tema.

No trabalho, foi primeiramente desenvolvida pesquisa sobre a parte teórica do instituto, a fim de fixar o embasamento jurídico sobre qual repousa o instituto.

Logo após, adentramos no instituto para entender seu funcionamento no Novo Código Civil e sugerir uma uniformização de sua efetiva aplicação. 


\section{SUMÁRIO}

\section{Conteúdo}

INTRODUÇÃO

PARTE I - DO INSTITUTO DA EXCLUSÃO DO SÓCIO ....................................... 10

CAPÍTULO I - CONCEITO E FUNDAMENTAÇÃO TEÓRICA .................................... 10

1.1 Considerações Iniciais ............................................................ 10

1.2 O Princípio da Preservação .............................................................. 11

1.3 Exclusão do Sócio x Dissolução Parcial............................................ 13

1.4 Fundamentação Teórica................................................................... 14

1.4.1 Teoria do Poder Corporativo ….................................14

1.4.2 Disciplina da Teoria Taxativa ..................................15

1.4.3 Disciplina Contratualista .......................................16

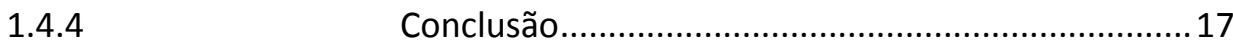

CAPÍTULO II - DA AFFECTIO SOCIETATIS ......................................................... 19

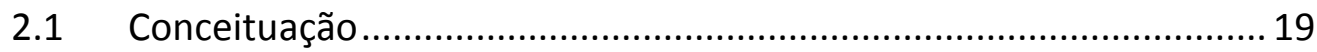

2.2 Affectio Societatis x Fim Social .......................................................... 21

2.3 Quebra da Affectio Societatis e Exclusão do Sócio. ............................ 22

PARTE II - DO PROCEDIMENTO DA EXCLUSÃO DO SÓCIO NO CÓDIGO CIVIL ... 25

CAPÍTULO III - EXCLUSÃO DO SÓCIO NO CÓDIGO CIVIL BRASILEIRO DE 2002 .. 25

3.1 Da exclusão Extrajudicial do Sócio Minoritário por Justa Causa ........ 25

3.1.1 Do procedimento da Exclusão Extrajudicial por Justa Causa ...................28 


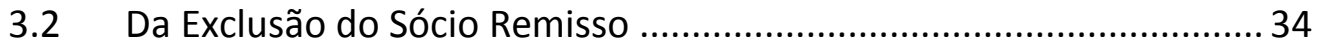

3.3 Exclusão na Sociedade composta por dois Sócios ............................. 36

3.4 Procedimento Judicial da Exclusão do Sócio....................................... 37

3.4.1 Exclusão de Sócio Majoritário por Falta Grave...........38

3.4.2 Exclusão de Sócio por Incapacidade Superveniente 39

3.4.3 Exclusão do Sócio Falido …….................................... 41

3.4.4 Exclusão por Quota Penhorada ...............................42

CAPÍTULO IV - APURAÇÃO DE HAVERES................................................. 43

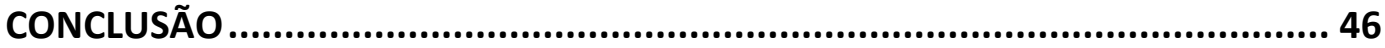

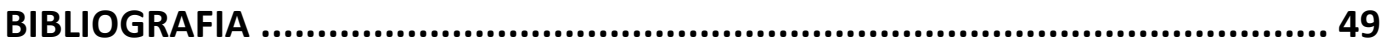


LISTA DE TABELAS E ABREVIAÇÕES

CC - Código Civil de 2002

CF - Constituição Federal 


\section{INTRODUÇÃO}

\section{Apresentação do tema}

O tema objeto deste estudo tem sido pauta para discussão há longa data, época em que o único diploma regulador do direito empresarial era o Código Comercial. Desde então, multiplicaram-se as teorias acerca da possibilidade da exclusão do sócio na sociedade comercial, que até os dias de hoje não possui entendimento consolidado.

Com a entrada em vigor do novo Código Civil, em 2002, novos dispositivos foram introduzidos pelo legislador para regular o instituto da exclusão de sócio que passou a ter uma regulamentação mais bem definida.

No entanto, nem de longe a nova legislação civilista foi suficiente para encerrar os debates acerca do tema que se arrastam por décadas, sendo possível uma análise crítica dos diversos pontos controversos desse importante procedimento.

\section{Metodologia}

Este estudo foi desenvolvido através de ampla análise principalmente doutrinária, sendo considerada uma larga gama de comentaristas sobre o tema, inclusive na doutrina internacional.

A Jurisprudência dos tribunais pátrios também foi objeto deste estudo, ajudando a consolidar o posicionamento apresentado. Importante é salientar que identificou-se uma polaridade de posicionamentos doutrinários bem distinta: enquanto parte dos autores preocupa-se acentuadamente com a proteção do sócio minoritário, inclusive tentando atrelar a sua condição de sócio direitos fundamentais, outra entende que o direito da exclusão seria faculdade da maioria, podendo ser exercido de forma quase indiscriminada.

\section{Plano de trabalho}


A presente monografia foi desenvolvida em duas partes - quatro capítulos. Na primeira parte foi estudada a exclusão de sócio como instituto, sua conceituação e fundamentação teórica, e reservou-se uma parte especial ao estudo da affectio societatis e suas implicações para o instituto da exclusão de sócio.

Já a segunda parte foi dedicada ao procedimento da exclusão do sócio, e à posterior apuração de haveres do sócio excluído, fundamental para que o instituto não seja utilizado como via arbitrária de exclusão por parte da maioria. 
PARTE I - DO INSTITUTO DA EXCLUSÃO DO SÓCIO

\section{CAPÍTULO I - CONCEITO E FUNDAMENTAÇÃO TEÓRICA}

\subsection{Considerações Iniciais}

A empresa privada é hoje o vértice da sociedade econômica moderna sendo responsável pela produção de riquezas, geração de empregos e recolhimento de tributos nas nações. Considerando a preponderância de seu papel na sociedade, deve ser na medida do possível conservada, uma vez que estabelecida atende tanto aos interesses dos sócios quanto assume um papel importante para a economia, muitas vezes em âmbito nacional.

Tal importância pode ser vista com mais clareza nos dias atuais pelo número em vigor de recuperações judiciais de empresas de grande porte, um claro reconhecimento de sua importância à sociedade como um todo.

Mediante a observância do princípio da preservação, os sócios devem, enquanto perdurar sua funcionalidade e rentabilidade, tentar preservar a empresa, e é justamente sob este prisma que deve ser enxergado o instituto da exclusão do sócio, como uma ferramenta com a qual a sociedade se livra de uma engrenagem emperrada, que esteja comprometendo seu bom funcionamento.

Ora, parece acertado entender que uma sociedade não está fadada a findar só porque um de seus sócios deixa de cumprir suas obrigações sociais, ou por motivos diversos decide atrapalhar os negócios sociais. Sobre a exclusão de sócio, entende Fábio Konder Comparato:

"No momento que se percebeu que para a sobrevivência da empresa era mister, muitas vezes, a eliminação de um sócio na sociedade mercantil, foi preciso que os juristas excogitassem explicações, ou melhor, justificações para tanto".

A exclusão de sócio consiste no afastamento forçado do sócio descumpridor de suas obrigações sociais, embora haja na doutrina, como analisado posteriormente, entendimento de

\footnotetext{
${ }^{1}$ COMPARATO, Fábio Konder. Exclusão de Sócio nas Sociedades de Responsabilidade Limitada. Revista de Direito Mercantil. São Paulo, n. 25, 1977, p. 40.
} 
que a simples desinteligência entre os sócios, ou a perda do animus inicial pelo qual se constituiu o vínculo social já seria suficiente para acarretar a exclusão do sócio.

Os ensinamentos de Fábio Ulhôa Coelho ${ }^{2}$ e de larga doutrina corroboram o texto legal: não é suficiente mera vontade da maioria, é preciso sempre que a exclusão do sócio seja feita de maneira motivada.

Não pode o sócio que cumpre com suas obrigações sociais e não é causador de discórdia ou desavenças ser excluído apenas por assim julgarem conveniente os demais. Nas palavras do citado doutrinador, "essa modalidade de desvinculação não é manifestação de vontade discricionária da maioria".

Estudando-se que a causa da expulsão de um determinado sócio da sociedade é uma "determinada causa", é possível imaginar hipótese de exclusão de sócio majoritário que cometesse tais atos.

No tocante a este ponto, observa-se uma diferença fundamental entre os sócios: enquanto o minoritário pode ser excluído por deliberação dos demais sócios, o majoritário só pode ser excluído por via judicial, até porque obviamente jamais se conseguiria obter o quórum necessário para expulsá-lo pela via extrajudicial. Abordaremos com mais ênfase esse ponto no seguimento do trabalho.

A exclusão do sócio, como comentado por toda doutrina, vem se firmando como um dos institutos de suma importância para o direito societário moderno, motivo pelo qual passamos a estudar suas peculiaridades nos itens que se seguem.

\subsection{O Princípio da Preservação}

Como já anteriormente mencionado, um dos pilares mais importantes no qual se sustenta a exclusão do sócio é no princípio da preservação da empresa. Tal princípio, segundo José Waldecy Lucena, viria se firmando inclusive como um direito fundamental do direito societário moderno.

\footnotetext{
${ }^{2}$ COELHO, Fábio Ulhôa. Curso de Direito Comercial. 5. Ed. São Paulo: Saraiva, 2002. V.2, p.417.
} 
O que o instituto da exclusão dos sócios busca é evitar a dissolução social. Como veremos adiante, todos os movimentos sejam eles tomados judicialmente ou extrajudicialmente, são no sentido de dirimir o conflito causado pelo sócio problemático sem que haja a necessidade da extinção da empresa.

Foi sob influência do princípio da preservação que surgiu na doutrina a idéia de que a titularidade do direito da exclusão do sócio não seria dos sócios que pleiteiam a saída do sócio problemático, mas sim da própria empresa. Sua vontade então se manifestaria através dos sócios, que procedem à exclusão do sócio problemático.

Nesse ponto, pede-se vênia para divergir da parte da doutrina que liga o princípio da preservação da empresa ao princípio da função social da empresa. Ora, em que pese sua já comentada importância para a economia moderna, a empresa deve ser resguardada e preservada não porque à coletividade tem interesse em sua sobrevida, mas porque os próprios sócios que a constituíram demonstram tal interesse.

Por isso, no que tange à exclusão do sócio, não prevalece qualquer interesse da sociedade sobre a continuidade ou não dos negócios sociais. A finalidade social, que será cotejada adiante, é obter lucro para ser dividido entre os sócios, e o princípio da preservação é invocado para salvar a empresa lucrativa, que desenvolve satisfatoriamente suas atividades e está ameaçada por um ente problemático.

Neste sentido, somos obrigados a discordar diametralmente daqueles que, como Waldo Fazzio, ligam o princípio em tela ao interesse da coletividade. O princípio da preservação não é exclusivamente aplicável à empresas que atravessam por dificuldades econômicas. Muito pelo contrário, deve sim ser aplicado para preservar empresas saudáveis e rentáveis que por algum motivo, como no caso específico deste estudo um sócio problemático, estejam a risco de encerrarem suas atividades.

Portanto, o que se deve observar sob o olhar do princípio da preservação, no caso específico da exclusão de sócio, é a vontade dos sócios em manter o negócio, e não da sociedade (podem bem estes optarem pela dissolução da sociedade, se assim entenderem), e a possibilidade de sua aplicação tanto a empresas deficitárias quanto saudáveis. 


\subsection{Exclusão do Sócio x Dissolução Parcial}

Larga doutrina tende a equiparar os institutos da dissolução parcial e da exclusão de sócios. Não obstante, como bem anota Celso Barbi Filho ${ }^{3}$, "evidencia-se que, enquanto na dissolução parcial o pleito de retirada é ato do sócio, na exclusão a saída lhe é imposta pelos demais, num ato de expulsão"

A dissolução parcial é ato de iniciativa do sócio, enquanto que a expulsão é ato coercitivo onde a sociedade em si, através dos demais sócios que impõem, seja através da via judicial ou extrajudicial, sua expulsão.

Outra distinção importante dá-se no quesito motivação: como analisamos acima, a exclusão de sócios é ato que sempre deve ser justificado, ou seja, sua implementação depende de motivação válida, enquanto a dissolução parcial é por regra, exercida de maneira imotivada.

Enquanto o instituto da exclusão de sócios é de dupla via (judicial ou extrajudicial), a dissolução parcial sempre pressupõe pleito judicial contencioso para que seja decretada a saída do sócio.

Ou seja, enquanto no caso de sócio minoritário sua saída pode ser determinada por uma alteração contratual, deliberando sua saída, a dissolução parcial deve necessariamente passar pelo crivo do judiciário.

O mestre José Waldecy Lucena ${ }^{4}$ com precisão anota:

"Para nós, o direito de recesso e o instituto de exclusão de sócio são causas de podem gerar o efeito de dissolução parcial da sociedade. É que se o sócio retirante ou o excluído aceitam os valores que lhes são pagos por seus haveres na sociedade, não há invocar, como parece óbvio, a construção pretoriana da dissolução parcial da sociedade."

É importante frisar, que embora a distinção entre os institutos esmiuçada acima seja evidente e corroborada por relevante doutrina, não há unanimidade doutrinária sobre o tema, sendo possível encontrar ainda autores que equiparem os institutos.

\footnotetext{
${ }^{3}$ FILHO, Celso Barbi. Dissolução Parcial de Sociedades Limitadas. Belo Horizonte: Mandamentos, 2004, p. 271.

${ }^{4}$ LUCENA, José Waldecy. Das Sociedades Limitadas. 6.ed. Rio de Janeiro. Renovar, 2005, p.780.
} 


\subsection{Fundamentação Teórica}

Como solidificado por larga doutrina, são três as teorias que buscam justificar o instituto da exclusão do sócio: (a) a Teoria do Poder Corporativo, (b) a Teoria Taxativa Legal e (c) a Teoria Contratualista. Como fica evidente a partir da análise que se segue, nenhuma das teorias descritas atende com perfeição ao embasamento teórico necessário para fundamentar o Instituo objeto deste estudo.

\subsubsection{Teoria do Poder Corporativo}

Para os seguidores desta teoria a exclusão do sócio se justificaria na soberania estatutária disciplinar sobre os sócios. Por este prisma, é possível enxergar a sociedade como um ente com legítima autonomia discricionária em relação aos sócios, que a ela ficam subordinados.

Esta soberania inclusive impediria que o mérito da exclusão viesse a ser apreciado pelo Judiciário, sendo a lei apenas o reconhecimento jurídico da exclusão, como indica Avelãs Nunes ${ }^{5}$, em aclamada monografia:

"O ente colectivo estaria investido de investido de uma legítima supremacia discricionária em relação aos sócios, de tal modo que o procedimento de exclusão seria inapreciável, quanto ao mérito, por parte do juiz."

Vale anotar que, por se tratar de poder corporativo estatutário a sociedade só poderia exercer a exclusão nos casos fixados em seu contrato social, devendo as hipóteses de exclusão ser enumeradas exaustivamente, e a exclusão se dando de forma a meramente aplicar os dispositivos constantes no contrato social.

Aqui, é comum concluir-se que a exclusão do sócio é então de titularidade não dos demais sócios que deliberam a exclusão de sócio excluído, mas da própria sociedade, que

\footnotetext{
${ }^{5}$ NUNES, A. J. Avelãs. O Direito de Exclusão dos Sócios nas Sociedades Comerciais. São Paulo, Cultural Paulistana,
} 2001. 
exerce o poder disciplinar de forma a efetuar a exclusão do sócio nos casos específicos previstos em seu contrato social.

Esta teoria encontra forte resistência doutrinária, principalmente no tocante ao poder disciplinar absoluto exercido pelos sócios. Na verdade, não se pode admitir que esse poder esteja imune de controle judicial, pois estaria se conferindo desta forma poder discricionário na mão da maioria.

Outra crítica tecida é sobre o poder disciplinar em si, pois em conformidade com o entendimento de Priscila M.P. Corrêa da Fonseca", "nem sempre a exclusão significa uma sanção, pois pode haver situações em que a expulsão se dá independentemente de culpa do sócio".

Embora as deficiências apontadas sejam de suma relevância, colheu-se dessa teoria o ideia de que de fato a titularidade do direito de excluir o sócio problemático não é dos demais sócios da sociedade, e sim da própria sociedade, que manifesta essa vontade através dos demais sócios, que deliberam sua exclusão.

\subsubsection{Disciplina da Teoria Taxativa}

Segundo o citado Avelãs Nunes, os precursores desta corrente teórica foram os alemães Erzbach e Alexander Katz que entendiam que o fenômeno da exclusão do sócio só poderia ocorrer com o objetivo de se preservar a empresa. Entendia-se, assim, que a exclusão só poderia ser feita em casos expressamente previstos em lei, sempre a título sancionatório.

Para tanto, seria imperioso se verificar o interesse público na continuidade do exercício pela empresa de suas atividades, que se daria através da exclusão do sócio causador dos problemas na sociedade.

Sendo assim, a exclusão de sócio teria um caráter penal, restritivo e excepcional, sendo vedada a aplicação analógica. Essas características ajudaram a cunhar a designação da teoria.

\footnotetext{
${ }^{6}$ FONSECA, Priscila M.P. Corrêa da.Dissolução Parcial, Retirada e Exclusão se Sócio. São Paulo, Atlas, 2002, p. 39.
} 
Esta teoria é duramente criticada por relevante doutrina, principalmente no quanto a constituir o interesse público o motivador da exclusão, a fim de preservar a empresa. Como citado anteriormente, é claro que a empresa desenvolve hoje papel central no desenvolvimento econômico, mas parece juridicamente inconsistente tirar daí a conclusão de que a coletividade teria interesse em sua manutenção em detrimento do interesse dos próprios sócios.

Não pode a coletividade, por exemplo, impor a exclusão do sócio como via de continuidade dos negócios sociais se a vontade dos sócios for no sentido de desconstituir a sociedade, encerrando os negócios sociais.

Outro ponto atacado pela doutrina é a taxatividade prevista na teoria. Não parece razoável, para um instituto que visa proteger a empresa, de que todos os casos de exclusão devam-se ater à letra da lei.

Em sentido contrário, parece justo entender que o direito à exclusão estaria naturalmente consentido, podendo ser aplicado em todos os casos nos quais algum dos sócios ponha em risco a continuidade dos negócios sociais.

É que a empresa moderna é um ente em constante evolução, sendo possível entender que surjam novas situações, pautadas nem novas descobertas e avanços tecnológicos, em que o sócio venha prejudicar o bom desenvolvimento dos negócios sociais de uma forma que antes não seria possível, logo não estaria prevista na legislação.

Por fim, é criticado pela doutrina o caráter punitivo que esta teoria tenta atribuir ao instituto da exclusão de sócio. A exclusão não é uma sanção nem tem caráter punitivo: é meramente uma proteção que a sociedade tem contra um ente que esteja pondo em risco seu bom funcionamento.

\subsubsection{Disciplina Contratualista}

Para muitos, o fundamento da exclusão do sócio teria abrigo no próprio contrato social, representando uma resolução da sociedade em relação ao sócio que descumpriu o pacto social. 
O código Civil Italiano de 1942 apegou-se a essa teoria contratualista, no sentido de remeter a exclusão do sócio aos princípios gerais dos contratos. Desta forma, como nos contratos plurilaterais, o inadimplemento ou impossibilidade superveniente de uma das partes a cumprir o contrato não resolve o contrato em face dos demais (arts. 1.420, 1.4559 e 1.466 do Código Civil Italiano de 1942).

Porém, tal teoria também é duramente criticada pela doutrina. Entende-se que, se pudesse equiparar o contrato social com um contrato sinalagmáticos no qual os sócios teriam entre si obrigações recíprocas, o resultado imediato do não cumprimento das obrigações por parte de um dos sócios é a dissolução total do contrato, e não a exclusão do sócio descumpridor.

Há um ponto nebuloso, no entanto, sobre a incidência ou não do sinalagma nas obrigações sociais estabelecidas no contrato social.

Mesmo que assim seja, maciça doutrina corrobora o pensamento de Avelãs Nunes, no sentido de que independentemente do tipo contratual que se identifica no contrato social, o sinalagma parece estar sempre presente na relação contratual, o que acarretaria a dissolução total do contrato em caso de descumprimento.

\subsubsection{Conclusão}

Consideradas as três teorias, pode-se concluir que não há uma justificativa teórica definitiva que embasa a exclusão do sócio, o que não importa em dizer que o instituto fique desvalorizado por este motivo.

Pelo contrário, o ponto único em que a totalidade da doutrina converge ao criticar as teorias é de que o instituto da exclusão assume cada vez mais papel de extrema relevância no mundo empresarial moderno.

Parece certo que, embora na ausência de uma teoria própria que justifique a razão de ser do instituto, dois pilares fundamentais podem ser identificados: o princípio da preservação 
da empresa, de que se tratou anteriormente, e a justa causa como cláusula potestativa, como analisaremos mais tarde.

Estes dois pilares sustentam o instituto da aplicação do sócio, e garantem uma aplicação coerente evitando abusos por parte da parte excludente. 


\section{CAPÍTULO II - DA AFFECTIO SOCIETATIS}

Um dos conceitos mais relevantes e debatidos, em se tratando de direito societário em geral é a affectio societatis. Tal conceito é alvo de árduo embate na doutrina, e tem influência direta no tema objeto deste trabalho, pois discute-se arduamente se sua quebra seria suficiente para determinar a exclusão do sócio da sociedade.

Faz-se necessário, então, análise sobre as relações entre os sócios e suas repercussões para a vida da sociedade.

\subsection{Conceituação}

A tarefa de se atribuir um conceito definitivo para o termo affectio societatis tem sem mostrado árdua para doutrina, em âmbito nacional e internacional. À primeira vista, uma tradução interpretativa literal nos leva a crer que o conceito adequado para o expressa uma intenção de constituir uma sociedade, conceito esse que é bem difundido, ainda que de forma superficial.

No plano internacional a doutrina e tribunais franceses acabaram por estabelecer que a affectio seria "o desejo, a vontade e a intenção de colaboração voluntária e ativa, interessada e igualitária". Por mais que a versão francesa da interpretação pareça mais acurada do que as anteriores, ainda é insuficiente.

Parece inadequado considerar a igualdade entre os sócios, uma vez que é perfeitamente concebível que haja sociedades com disparidades consideráveis em termos de participação societária, sócios que tenham funções administrativas, ou ainda sócios que contribuam de formas diferentes para a formação do capital social (por conferência de um bem em detrimento de dinheiro, por exemplo).

Segundo o importante comentarista sobre o tema Joseph Hemel, não pode o contrato social ter como critério a intenção de constituir uma sociedade. Isso por que a sociedade uma vez constituída já ultrapassou a alçada da intenção, tendo sido regularmente constituída, como parece óbvio constatar. 
Segundo o jurista, à affectio também se atribui outro elemento: a aceitação do risco pelos sócios contratantes, sendo o conceito composto dessa forma de (i) vontade de união dos agentes e (ii) aceitação por estes das áleas comuns do negócio.

Tal união não implicaria, divergindo do entendimento do judiciário francês, um uma colaboração igualitária dos integrantes, apenas na efetiva organização destes objetivando o fim social.

Ainda assim o conceito parece insuficiente, como anotam Erasmo Valladão Azevedo e Novaes França e Marcelo Vieira Von Adamek:

\footnotetext{
"Ainda aqui, o conceito de affectio societatis aparece como mero critério de distinção da sociedade com outros contratos, e, por ser meramente descritivo, não fornece nenhum instrumento útil para lidar com problemas que digam respeito à dissolução da sociedade ou do vínculo contratual que une o sócio à sociedade".
}

Do mesmo modo, a doutrina nacional encontra a mesma dificuldade para conceituar o termo. O mestre Waldírio Bulgarelli tem clássica concepção de affectio societatis, pela qual esta seria a intenção dos sócios de se reunirem para a realização do fim comum.

Porém, deve-se anotar que apesar do fim comum ser de fato elemento essencial para a constituição do vínculo societário, é criticável o conceito no que tange a intenção dos sócios, por ser critério demasiadamente subjetivo.

O que parte da doutrina tenta implicar, e que se pode rebater, é que o affectio societatis seria um elemento específico e constitutivo do contrato social, que o diferiria dos outros tipos de contrato.

Ocorre que, em verdade, a affectio que impulsiona a constituição do contrato social não constitui espécie de consentimento especial que diverge dos demais contratos, sendo equiparada analogicamente à atuação das partes num contrato de colaboração de longo prazo.

Assim, o que se conclui é que não é o elemento intenção de contratar, mas sim o fim social, que constitui característica diferenciadora nos contratos sociais.

\footnotetext{
${ }^{7}$ NOVAES E FRANÇA, Erasmo Valladão Azevedo e; ADAMEK, Marcelo Vieira, "Affectio Societatis: um conceito Jurídico Superado no Moderno Direito Societário pelo Conceito de Fim Social", Revista de Direito Mercantil, industrial econômico e financeiro, São Paulo, Melhoramentos, vol. 149/150, jan./dez. 2008, p. 114.
} 


\subsection{Affectio Societatis $\mathrm{x}$ Fim Social}

Pelo exposto, percebe-se a enorme dificuldade de se obter um conceito de affectio societatis suficientemente completo, que o colocaria como vértice da constituição da empresa moderna.

Tal dificuldade levou a doutrina recente a considerar o esvaziamento e abandono do conceito, substituindo-o por outro elemento, que seria o principal pilar no qual se apoia a empresa moderna: o fim comum.

Nas sociedades limitadas, o fim comum ou social é constituído pelo (i) objeto social, que é o caminho pelo qual os sócios buscarão atingir social, e (ii) pelo objetivo social, que é sempre obter lucros com a atividade exercida.

O Código Civil determina em seu artigo 981 que "celebram contrato de sociedade as pessoas que reciprocamente se obrigam a contribuir, com bens ou serviços, para o exercício de atividade econômica e a partilha, entre si, dos resultados.". Do texto legal extrai-se uma única conclusão lógica, de que nas sociedades comerciais, especialmente nas limitadas, independentemente do objeto social, o objetivo é sempre igual: obter lucro.

O conceito de affectio societatis como elemento definidor das sociedades comerciais demonstra-se obscuro e confuso: poderiam ser consideradas discórdias pessoais entre os sócios suficientes para quebrar o affectio? A mera perda de vontade de união dos sócios se unirem é suficiente para o desmantelamento da sociedade?

Por outro lado, o conceito de fim comum parece muito mais objetivo e suficiente para regular as atividades sociais. Sob este conceito bastaria analisar se o sócio pratica atos que (i) opõe-se frontalmente ao objeto social, conforme definido no contrato social ou (ii) trazem prejuízos econômicos diretos ou indiretos para a sociedade para determinar uma infração passível de exclusão.

Não se pode negar a importância do sócio minoritário para a empresa moderna, que sem dúvida constitui uma forma importante para se atrair recursos e aumentar o poderio econômico da mesma. 
A prevalência do conceito de affectio societatis como elemento definidor da exclusão do sócio traria uma enorme insegurança ao sócio minoritário, que poderia ser excluído por diversos motivos que pudessem ser justificados como quebra do affectio, o que poderia acarretar a retirada ou o não ingresso de novos sócios às empresas.

Logo, o que ora se sugere é que essa mudança conceitual seja feita a fim de trazer maior segurança jurídica para o instituto da exclusão do sócio, futuramente padronizando o procedimento, para não reste dúvida sobre em quais casos o sócio pode ser excluído.

\subsection{Quebra da Affectio Societatis e Exclusão do Sócio.}

Apesar dos problemas conceituais acima apontados a quebra do affectio societatis ocupou largo espaço na doutrina como uma das possibilidades para a exclusão do sócio. É que se considerou que seria motivo suficiente para a que a maioria delibere pela exclusão de um sócio o fim da vontade manter vivo o vínculo associativo para com o excluído.

E assim entendeu José Waldecy Lucena ${ }^{8}$ :

"E parece claro que a "justa causa", o "motivo grave", o "motivo legítimo", o "ato irregular", etc., traduzirão em regra um inadimplemento contratual, principalmente a quebra do affectio societatis."

É bom anotar que a posição do doutrinador vinha sendo corroborada não só por vasta doutrina, mas também pelos tribunais pátrios, em diversas oportunidades decidiram por aceitar a exclusão do sócio sob a justificativa de que ocorrera no caso concreto a quebra do affectio, principalmente antes da entrada em vigo do Código Civil de 2002.

Assim foi o entendimento do egrégio Tribunal de Justiça do Estado do Rio de Janeiro ${ }^{9}$ :

“DIREITO EMPRESARIAL. SOCIEDADE POR COTAS DE RESPONSABILIDADE LIMITADA. Ação proposta por sócio minoritário excluído por força de ato unilateral dos outros, praticado antes da vigência do Código Civil de 2002. Dentre outros, pedido de declaração da nulidade do ato expulsório, de dissolução total da sociedade, de realização de auditoria contábil e de indenização por danos morais. Sentença de improcedência. Reforma do ato judicial, por maioria,

\footnotetext{
${ }^{8}$ LUCENA, José Waldecy. Da Sociedade Limitada. 6.ed., Rio de Janeiro, Renovar, 2005, p. 724.

${ }^{9}$ Embargos Infringentes no 0030003-57.2005.8.19.0001, Terceira Câmara Cível, Tribunal de Justiça do RJ, Relator: Fernando Foch Lemos, Julgado em 08/07/2008
} 
com provimento do apelo do sócio excluído. Voto vencido no sentido do desprovimento do recurso, ao entendimento de não ser razoável anular a dissolução parcial da sociedade para, em seguida, determinar sua dissolução integral; e de não ser esta a via adequada à realização de auditoria, mas sim a da ação de apuração de haveres. Embargos infringentes. 1. Não há que se falar em violação ao direito à ampla defesa quando inexistir processo jurisdicional, judicial ou administrativo. A norma constitucional visa assegurar o devido processo legal, não sendo aplicável a atos alheios à jurisdição.2. A perda da affectio societatis na sociedade limitada sociedade de pessoas,configura justa causa para exclusão de sócio minoritário pelos majoritários, mesmo que não haja previsão expressa no contrato social nesse sentido.3. Sendo a exclusão do sócio ato lícito, não há falar em indenização do excluído por dano moral.4. Em trâmite apuração de haveres, descabe determinar auditoria na sociedade.5. Provimento dos embargos. Maioria." (Grifou-se).

No mesmo sentido entendeu o Tribunal de Justiça de São Paulo ${ }^{10}$ :

“Apelação Cível. Ação de exclusão de sócio cumulada com indenização por perdas e danos (receita apropriada indevidamente). Incontroversa a quebra da affectio societatis, deve prevalecer a decisão da maioria. Exclusão do sócio com apuração de haveres em sede de liquidação Afastada a indenização por perdas e danos. Valores auferidos pelo réu, como pessoafísica, em decorrência de palestras por ele ministradas, atividade anterior ao seu ingresso na sociedade. Receita que não integra o resultado das atividades da empresa-autor.a Cursos ministrados pelo sócio-réu diversos dos oferecidos pela empresa-autora, caracterizando atividade paralela Manutenção da sentença. Nega-se provimento ao recurso de apelação." (Grifou-se).

O tema é, sem sombra de dúvidas, controverso. Demonstrando a disparidade doutrinária na temática, anota com precisão Arnoldo Wald ${ }^{11}$ que "o Superior Tribunal de Justiça tem entendido que a dissolução parcial pode se dar pela quebra da affectio societatis, o que porém, não é fundamento para a exclusão do sócio".

Neste prisma, é possível também encontrar na jurisprudência pátria diversos julgados considerando insuficiente a quebra do affectio como justo motivo para excluir-se sócio da sociedade, como entendeu o Tribunal de Justiça do Estado de São Paulo ${ }^{12}$ :

\footnotetext{
"RECURSO PRINCIPAL. DIREITO SOCIETÁRIO. Pretensão de exclusão de um dos sócios por falta grave. Descabimento. Perda incontroversa da "affectio societatis" não sustenta por si só o pedido de exclusão. Divergência entre dois grupos societários, cada um com $50 \%$ do capital, quanto a quem compete a administração da empresa. Inexistência do desinteresse de colaboração para o cumprimento do objetivo comum. Desinteligência na verdade acerca de qual seria o melhor projeto de administração para a continuidade da empresa. Contrariedade."

${ }^{10}$ Apelação no 9100098-30.2006.8.26.0000, Quinta Câmara de Direito Privado, Tribunal de Justiça de SP, Relatora: Christine Santini, Julgado em 03/08/2011.

${ }_{11}^{1}$ WALD, Arnoldo, Comentários ao Novo Código Civil, v. XVI, t. II, Rio de Janeiro: Forense, 2005, p. 235.

${ }^{12}$ Apelação no 0002402-02.2009.8.26.0564, Quinta Câmara de Direito Privado, Tribunal de Justiça de SP, Relator: James Siano, Julgado em 25/05/2011.
} 
A divergência doutrinária que repercute nos tribunais de todo o país levou o Egrégio Superior Tribunal de Justiça a editar o Enunciado no 67 do CEJ, no qual lê-se que "a quebra no affectio societatis não é causa para exclusão do sócio minoritário, mas apenas para a dissolução parcial da sociedade".

Parece sábio e acertado o entendimento do Superior Tribunal de Justiça, tentando evitar é a discricionalidade na exclusão do sócio. Pela nebulosidade que paira sobre o conceito de affectio societatis, seria possível se admitir se deliberar a exclusão de sócio minoritário de sociedade comercial apenas pela simples vontade da maioria, sob a mera justificativa de problemas de ordem pessoal.

Veremos posteriormente, ao conceituar a justa causa pelo qual o sócio pode é passível de exclusão da sociedade, como essa derrocada da utilização do conceito de affectio societatis se evidencia, e a tentativa da doutrina de estabelecer parâmetros mais objetivos para a aplicação do instituto. 


\section{PARTE II - DO PROCEDIMENTO DA EXCLUSÃO DO SÓCIO NO CÓDIGO CIVIL}

\section{CAPÍTULO III - EXCLUSÃO DO SÓCIO NO CÓDIGO CIVIL BRASILEIRO DE 2002}

Hoje a exclusão do sócio encontra amparo legal no Código Civil Brasileiro, sancionado em 2002, que observando o princípio da preservação das sociedades comerciais, consagrou o instituto da exclusão do sócio.

No citado dispositivo legal, encontram-se as modalidades para a exclusão dos sócios, sejam elas:

(a) a não integralização do valor subscrito da quota dentro do prazo estabelecido para subscrição (sócio remisso);

(b) falência ou insolvência do sócio;

(c) liquidação de quota penhorada;

(d) incapacidade superveniente sócio;

(e) falta grave no cumprimento de suas obrigações

(f) exclusão do sócio por justa causa.

Nota-se neste ponto, que apesar do referido diploma ter enumerado diversas possibilidades da exclusão de sócio tal enumeração não é taxativa. Nem poderia ser, pois ao autorizar a exclusão extrajudicial do sócio por justa causa, o legislador abriu mão do controle sobre quais casos seriam passíveis de exclusão.

\subsection{Da exclusão Extrajudicial do Sócio Minoritário por Justa Causa}


A exclusão do sócio minoritário por justa causa é sem dúvida o ponto mais controverso da exclusão do sócio na sociedade limitada. O artigo 1.085 do Código Civil traz em seu texto a previsão legal desta modalidade, in verbis:

"Art. 1.085. Ressalvado o disposto no art. 1.30, quando a maioria dos sócios, representativa de
mais da metade do capital social, entender que um ou mais sócios estão pondo em risco a
continuidade da empresa, em virtude de atos de inegável gravidade, poderá excluí-los da
sociedade, mediante a alteração de seu contrato social, desde que previsto neste a exclusão por
justa causa".

Tal dispositivo legal traz desperta certo desconforto na doutrina, no que se refere à necessidade da previsão contratual para a possibilidade da exclusão extrajudicial do sócio.

Pela interpretação literal do dispositivo, as sociedades nas quais não há a previsão em seu contrato para a deliberação da exclusão do sócio pela via extrajudicial apenas poderiam recorrer à via judicial para a exclusão do sócio que causa problemas à sociedade.

Ora, como é cediço, a via judicial é morosa e por vezes pouco eficaz, ao que se estaria trazendo prejuízos irreparáveis à sociedade se esta tiver que esperar por sentença judicial para ter excluído um sócio que estivesse a lhe trazer prejuízos.

Torna-se imprescindível em certos casos o imediato desligamento do sócio da sociedade por isso o legislador nesse sentido agiu em contramão da doutrina e da própria evolução da empresa moderna.

Dessa forma entendeu de forma clara e concisa o já citado mestre José Waldeci Lucena $^{13}$ :

"Vide, pertinente ao tema, exemplo dos mais frequentes, qual o do sócio que entra a fazer concorrência desleal à sociedade, desviando-lhes clientes, know how, empregados, etc, para outra sociedade. Esse ilícito comportamente não pode esperar os morosos trâmites de uma ação judicial, para somente então se afastar o sócio desleal".

Parece acertada e sábia a colocação do mestre, que foi corroborada por larga e relevante doutrina, inclusive civilistas como Orlando Gomes e Miguel Reale.

\footnotetext{
${ }^{13}$ LUCENA, José Waldecy. Da Sociedade Limitada. 6.ed., Rio de Janeiro, Renovar, 2005, p. 726.
} 
Assim também vem entendendo a moderna jurisprudência, pelo que nossos tribunais pátrios diversamente se posicionaram no sentido de ignorar a não constância de cláusula específica para que se seja autoriazado à maioria deliberar sobre a exclusão de um sócio.

Outro ponto que merece mais detalhada é o conceito de justa causa, elemento essencial para a exclusão extrajudicial dos sócios. Segundo o mestre Modesto Carvalhosa ${ }^{14}$ :

\begin{abstract}
“Deve-se entender como justa causa da exclusão do sócio a conduta violadora de lei, bem como o inadimplemento de suas obrigações contratuais relevantes, sejam elas de contribuição para o capital social ou de colaboração na sociedade. (...) É preciso que esse descumprimento do contrato social resulte na quebra do affectio societatis, a ponto de romper o equilíbrio da relação sinalagmática de colaboração do sócio com o escopo comum."
\end{abstract}

Neste ponto, não se ignorando a reputação ilustre de que goza o doutrinador, permite-se discordar integralmente de seu posicionamento. É que, como já esmiuçado nos capítulos [...] anteriores, o conceito de affectio societatis é impreciso e a moderna doutrina aconselha a substituí-lo pelo conceito de fim social.

E por último, não parece certo que toda conduta violadora de lei implicaria em justa causa para a exclusão do sócio. Imaginemos um cenário no qual um sócio deixa de pagar pensão alimentícia, por exemplo. Ora tal postura, imoral que seja, não tem ligação alguma com a sociedade ou a traz malefício.

O mestre Alfredo de Assis Gonçalves ${ }^{15}$ neto anota:

"A simples alegação de perda de affectio societatis, por outro lado, não me parece e nem é, de modo algum, razão suficiente para autorizar a exclusão - vale dizer, não se enquadra no conceito de justa causa para exclusão, porqaunto advém, exclusivamente, de razões de foro íntimo."

Parece correto ligar a justa causa ao conceito de fim social, e não ao conceito de affectio societatis, então entendendo que seriam passives de exclusão atos praticados pelo sócio que (i) vão de encontro ao objeto social da sociedade ou (ii) estão em desacordo com a finalidade social, entende-se aqui, no caso das limitadas, é gerar lucro para ser repartido entre os sócios.

Por conseguinte, deve-se provar, no segundo caso, os prejuízos patrimoniais que o sócio vem causando a sociedade, sejam eles diretos ou indiretos.

\footnotetext{
${ }^{14}$ CARVALHOSA, Modesto, Comentários ao Código Civil: parte especial: do direito de empresa (arts. 1.052 a 1.195), vol. 13, São Paulo, Saraiva, 2003, p. 310/311.

${ }^{15}$ GONÇALVES NETO, Alfredo de Assis, Lições de direito societário, 2ạ ed., São Paulo, Juarez de Oliveira, 2004, p. 297.
} 
Outro ponto que causador de polêmica é se os atos, que configuram a justa causa para a determinação da exclusão seriam de natureza dolosa ou culposa. Há na doutrina defensores, inclusive dentre eles o citado Modesto Carvalhosa, da tese que apenas configurariam justa causa para exclusão os atos praticados com o intuito de lesar a sociedade, não se podendo excluir o sócio por ato que veio a praticar culposamente.

Não parece essa corrente correta, ao passo que não se pode admitir que fique a empresa à mercê do sócio que aja regularmente com imprudência ou seja imperito nas negociações, trazendo graves consequências para os demais, sendo certo que a prática do ato lesivo, independente de intenção, é suficiente para a configuração da justa causa necessária para a exclusão.

\subsubsection{Do procedimento da Exclusão Extrajudicial por Justa Causa}

Passamos então a análise do procedimento da exclusão de sócios. Há na doutrina relevante aspecto sobre a quem caberia tomar a medida de excluir o sócio faltoso: os sócios ou a sociedade.

O parágrafo único do artigo 1.085 do CC trouxe a seguinte redação:

“Parágrafo único. A exclusão somente poderá ser determinada em reunião ou assembleia especialmente convocada para este fim, ciente o acusado em tempo hábil para permitir seu comparecimento e direito de defesa."

Parece óbvia a conclusão de que quem delibera a exclusão, seja na assembleia ou na reunião são os sócios. Porém, há o entendimento doutrinário de que a deliberação uma vez tomada é da pessoa jurídica, e não mais dos sócios. Essa visão nos dá a entender de que o direito de exclusão do sócio por justa causa seria da própria sociedade, protegendo-se de um mal interno que está a Ihe afligir.

Analogicamente, desta forma entendeu o legislador ao editar a Lei das Sociedades Anônimas, ao redigir seu artigo 107, no qual lê-se que verificada a mora do acionista, cabe à companhia tomar as medidas para lidar com o acionista remisso. 
De acordo com o parágrafo único do art. 1.085 transcrito acima, o primeiro passo para a exclusão do sócio é a convocação de assembleia ou reunião extraordinária para este fim. 0 sócio excluendo deve ser avisado com antecedência para que possa comparecer à reunião, participando dos debates e exercendo seu direito de defesa.

Uma vez tomada a decisão, sempre mediante votação por maioria absoluta, a ata da reunião ou assembleia será lavrada, e então far-se-á o instrumento de alteração contratual na sociedade, homologando a saída do sócio excluído, a ser arquivado na Junta Comercial.

Um ponto relevante é o momento da exclusão do sócio, seja este o momento no qual o excluído perde sua qualidade de sócio. Nesse sentido, se tem entendido que os efeitos da exclusão inter sócios é imediatos, produzindo efeitos a partir da deliberação tomada na assembleia. No que tange à eficácia para com terceiros, somente esta se verificará após o registro da alteração contratual.

Assim entende a jurista M. P. Corrêa Fonseca ${ }^{16}$ :

“A exclusão opera seus efeitos a partir da deliberação que a proclame. A eficácia desta é, pois, imediata. Em relação ao sócio excluído, os respectivos efeitos somente começaram a fluir dado o respectivo caráter receptivo - com base na ciência da alteração processada e, relativamente a terceiros, a contar do arquivamento da alteração contratual a ser realizado perante a Junta Comercial."

\subsubsection{Do quorum para a Exclusão por Justa Causa}

O Código Civil foi cristalino ao determinar o quorum deliberativo para a exclusão do sócio: mais da metade do capital social votante. Tal quórum vale, logicamente, tanto para a instalação da assembleia ou reunião na qual se deliberará a exclusão do sócio, quanto para deliberar-se sua exclusão.

Notadamente, tendo em vista o artigo 1.074 \$2ำ do Código Civil, não poderá o sócio excluendo votar na assembleia que visa determinar sua exclusão, embora possa participar da

\footnotetext{
${ }^{16}$ FONSECA, Priscila M.P. Corrêa, da.Dissolução Parcial, Retirada e Exclusão se Sócio, São Paulo, Atlas, 2002, p.59.
} 
mesma (como analisado posteriormente). Não é este o motivo, porém, que levaria suas quotas a serem desconsideradas na formação do quorum deliberativo.

Ou seja, como se trata de maioria simples, não tendo o código se posicionado a respeito de quorum especial em matéria de exclusão do sócio, considerar-se-ão as quotas do sócio a ser excluído, que consideradas em conjunto com as demais, formarão o bojo das quais se necessita da maioria absoluta para deliberar-se a exclusão.

Percebe-se com a análise a impossibilidade latente de se deliberar a exclusão extrajudicial do sócio majoritário. Ora, jamais se chegaria ao quórum necessário para promover a exclusão extrajudicial se o sócio excluendo detém mais da metade das quotas representativas do capital social.

Cumpre ressaltar que, a despeito do texto legal, pode o contrato social de a sociedade prever quorum superior à maioria absoluta, caso no qual deverá se respeitar tal previsão contratual. Não se pode de forma alguma, no entanto, se estabelecer quorum inferior ao previsto no texto legal.

\subsubsection{Direito de Defesa do Excluendo}

$\mathrm{Na}$ exclusão por justa causa, apreciam-se atos graves que o sócio venha praticando ou tenha praticado, atos estes que podem inclusive por em xeque sua moral e caráter perante a comunidade.

Desde o início cumpre ressaltar que o direito de defesa do excluendo não se mistura com o direito de votar na assembleia convocada com fins especiais para se tratar da exclusão.

Isso porque, como reza o artigo 1.074, \$2 do CC, "nenhum sócio, por si ou na condição de mandatário, pode votar matéria que lhe diga respeito". Não fosse pelo texto legal, já seria incoerente se admitir que o sócio poderia votar em assembleia convocada especialmente para excluí-lo, afinal seu voto seria óbvio. 
O que se quer se tratar por direito de defesa é o direito do sócio de comparecer a sociedade e se defender das acusações que the são atribuídas, participando dos debates que precedem às deliberações.

A Carta Magna incluiu como garantia individual em seu art. 5ㅇ, LV, "aos litigantes, em processo judicial ou administrativo, e aos acusados em geral são assegurados o contraditório e ampla defesa, com os meios e recursos a ela inerentes".

O Código Civil no mesmo sentido determinou, no já referido parágrafo único do art. 1.085, que o acusado seja avisado em tempo hábil das acusações que lhe são atribuídas, para que possa comparecer a assembleia ou reunião e exercer seu direito de defesa.

Neste sentido, há uma importante discussão doutrinária. Enquanto parte da doutrina ressalta a importância do comparecimento do excluendo à assembleia/reunião que vise deliberar sua exclusão, é possível encontrar posicionamento diverso, entendendo que tal previsão não teria efeitos práticos.

Dentre os que defendem o direito de defesa do sócio excluendo, anota o já mencionado mestre Lucena ${ }^{17}$ :

\footnotetext{
“Mas, de não ter o direito de votar, não se infira que não terá o excluendo o direito de participar da assembleia/reunião, especialmente convocada para esse fim, qual o de deliberar sobre a acusação que lhe é feita, de produzir sua defesa e participar dos debates. Isso nada mais é do que o exercício de um dos direitos essenciais, decorrentes do status socii, que não são específicos das sociedades anônimas, como a cotio se pensa, mas de toda e qualquer sociedade $[\ldots] . "$
}

Por mais sentido que faça o raciocínio do ilustre doutrinador, uma análise mais prática deve ser feita a respeito do tema. Pouco adianta, para os fins de exclusão do sócio, que o sócio a quem se almeja excluir apresente sua defesa.

Como o direito de voto já Ihe foi vedado por lei, sua defesa apenas servirá para constar em registro, mas é utópico pensar de que os sócios deixarão de excluir o sócio pois este apresentou uma defesa contra os atos que lhe foram atribuídos.

\footnotetext{
${ }^{17}$ LUCENA, José Waldecy, Da Sociedade Limitada, 6.ed. Rio de Janeiro, Renovar, 2005, p. 744.
} 
E isso fica evidente, pois é de se imaginar que já houve apuração de fatos e discussões preliminares antes de se chegar a uma atitude drástica como a exclusão de um sócio da sociedade, atitude essa gravosa para a própria empresa.

E desse modo entendeu o douto Alfredo de Assis Gonçalves Neto ${ }^{18}$ :

“Parece-me, de todo modo, extremamente infeliz a previsão de exercício do direito de defesa, já que as deliberações sociais representam, pura e simplesmente, a somatória da vontade da maioria exigida para tomá-la - e não um julgamento . Se a maioria, com ou sem defesa do sócio excluendo decidir sua exclusão, ele tem todo o direito de invocar a proteção do Poder Judiciário para fazer cessar essa agressão ao seu direito de se manter como sócio, se tal direito existir."

É justo e claro o posicionamento de Gonçalves Neto. O sócio excluendo, encontrando-se em uma posição de injustiça ante a deliberação da maioria, deve procurar o Poder Judiciário, que obviamente tem competência para anular a exclusão feita de forma irregular.

Se de outro modo se entender, poderia se chegar à situação de impasse, na qual o sócio excluendo decide não comparecer, não se deixando notificar ou simplesmente não comparecendo à assembleia, e depois pode vir a arguir que a mesma não é válida por seu direito de defesa não ter sido exercido.

Não deve prosperar, noutra mão, a argumentação de que o direito de defesa seria imprescindível por representar um direito de defesa do acusado de sua honra ou moral, que podem estar sendo atacadas quando a ele são imputados atos de cunho imoral, por exemplo. Como exposto anteriormente, se assim for, o poder Judiciário é a via adequada para o sócio excluído buscar reparação.

Logo, o que se está defendendo não é a impossibilidade do sócio comparecer a reunião na qual se decidirá sobre sua exclusão. Nem haveria essa possibilidade: até o ato formal da deliberação dos demais sócios determinando sua exclusão, o sócio excluendo ainda goza da qualidade de sócio, e só não pode votar por se tratar de matéria relativa à sua pessoa.

O que se entende é que tal direito não seria fundamental, nesse sentido não sendo necessário o comparecimento do sócio nem o exercício de seu direito de defesa para que seja realizada a assembleia.

\footnotetext{
${ }^{18}$ GONÇALVES NETO, Alfredo de Assis, Lições de direito societário, 2ae ed., São Paulo, Juarez de Oliveira, 2004, p.300.
} 


\subsubsection{Do controle Judicial da Exclusão Extrajudicial}

No que concerne o controle Judicial da exclusão extrajudicial a doutrina é praticamente unânime, sendo tarefa árdua encontrar posicionamento que não sobre a independência absoluta da exclusão judicial sobre qualquer controle do Poder Judiciário. Em pequena parcela doutrinária, no entanto, há o entendimento de que pela gravidade que se atribui à exclusão do sócio, a mesma só poderia ser reconhecida por sentença judicial.

Analisando-se o procedimento da exclusão extrajudicial do sócio, é simples a conclusão de que tal procedimento se opera mediante ato da sociedade, não sendo necessário incursão do Poder Judiciário para validá-la.

O jurista Idevan César Rauen Lopes ${ }^{19}$ acertadamente justifica o procedimento de exclusão extrajudicial do sócio:

“A exclusão extrajudicial não agride o princípio do devido processo legal, pois se trata de um instituto fundamentado em lei e nos princípios básicos do Direito Comercial, e que não impede a apreciação pelo Judiciário da justa causa apontada no instrumento que excluirá o sócio faltante."

O controle judicial da exclusão processada em via administrativa se dará post factum. 0 sócio inconformado deverá recorrer ao poder judiciário, ao qual caberá análise do procedimento e a identificação de possíveis abusos por parte da maioria excludente.

Parece fundamental a possibilidade, neste sentido, do sócio excluendo recorrer ao poder judiciário para apreciação do ato de exclusão. O resultado disso é a regulamentação do poder da maioria, que já ciente da possibilidade do ingresso do sócio excluendo no Poder Judiciário, agirá com cautela para evitar que o sócio seja eventualmente reintegrado ao quadro social por força de sentença judicial ou decisão que suspenda a deliberação.

Outra questão que se levanta é o limite da atuação do judiciário. Poderia o juiz valorar as causas que motivaram a decisão ou deve o magistrado ater-se à legalidade do procedimento extrajudicial?

\footnotetext{
${ }^{19}$ Lopes, Idevan César Rauen. Empresa \& Exclusão do Sócio, 2a Ed. Curitiba, Juruá, 2008, p.137.
} 
No tocante a este ponto, majoritária doutrina converge para o entendimento de que o Poder Judiciário deve, quando provocado por um sócio inconformado com sua exclusão, averiguar não só se a aludida exclusão foi feita dentro dos ditames legais, mas também a justa causa que a motivou.

É que como já dito, busca-se evitar o abuso de poder por parte da maioria. Fosse a análise do Poder Judiciário limitada à legalidade do ato expulsatório, poderia a maioria promover a expulsão de maneira a respeitar todos as obrigações legais, mas com uma motivação incompatível.

O sócio inconformado com sua exclusão poderá então ingressar com ação anulatória contra a sociedade, pessoa jurídica, e não contra os sócios, pois como já cotejado anteriormente o ato da exclusão é de titularidade da sociedade.

No pleito judicial, o sócio excluído pode requerer a reintegração do quadro social, se demonstrada justa causa, no caso de alguma irregularidade formal de sua exclusão, podendo também discutir a apuração de haveres. Porém, jamais poderá requerer a dissolução parcial da sociedade, uma vez que este é um ato que depende da qualidade de sócio, já não mais ostentada por ele.

Caso reste demonstrada a ausência da justa causa para a exclusão do sócio, deverá ser reintegrado ao quadro social da empresa, podendo requerer indenização pelos danos causados tanto na esfera material, pelo tempo que ficou afastado da sociedade, quanto na esfera moral, pelas imputações inverídicas que Ihe tenham sido atribuídas.

\subsection{Da Exclusão do Sócio Remisso}

Ainda no que tange à exclusão extrajudicial do sócio, deparamo-nos com a figura do sócio remisso, figura que causa discussões pela imprecisão do art. 1.058, cujo texto lê-se abaixo:

\footnotetext{
“Não integralizada a quota de sócio remisso, os outros sócios podem, sem prejuízo do disposto no art. 1.004 e seu parágrafo único, tomá-la para si ou transferi-la a terceiros, excluindo o primitivo titular e devolvendo-lhe o que houver pago, deduzidos os juros da mora, as prestações estabelecidas no contrato mais as despesas."
} 
Pelo texto legal, não é possível distinguir se a exclusão mencionada no dispositivo seria pela via judicial ou extrajudicial. Porém, deve-se cotejar o art. acima referido com o art. 1.004, do mesmo diploma, que habilita aos sócios das sociedades simples a exclusão extrajudicial do sócio remisso.

Evidente que podem os sócios optar pela via judicial do sócio remisso, embasados no dispositivo encontrado no art. 1030 do CC, mas parece mais rápido e eficiente que a sociedade expurgue de uma vez o sócio que não integralizou as quotas de lhe caberiam, e deste modo prejudica a sociedade como um todo.

O procedimento para exclusão do sócio remisso é similar à exclusão de sócio por justa cauda. Devem os sócios se reunir em assembleia ou reunião especialmente convocada para este fim, na qual deliberarão a exclusão do sócio. A diferença se dá na necessidade de convocação do sócio excluendo, pois no caso do sócio remisso não há a exigência de sua convocação, e no quórum de instalação da assembleia ou reunião.

Isso porque, nesse caso, não há o exercício do direito de defesa, uma vez que só é permitido expulsar-se o sócio depois que estiver de fato em mora, ou seja, depois de transcorridos trinta dias da notificação enviada pela sociedade ao sócio remisso para que este integralize o capital sem que ele o faça.

Quanto ao quorum de instalação da reunião ou assembleia, a diferenciação entre o procedimento de exclusão do sócio remisso e o de exclusão por justa causa parece evidente. Enquanto neste para se estabelecer a maioria absoluta devem ser consideradas as quotas do sócio excluendo, naquele as quotas são ignoradas, só sendo levadas em consideração o capital devidamente integralizado.

É fácil chegar à esta conclusão quando analisamos o texto do já referido jurista Idevan César Rauen Lopes ${ }^{20}$ :

“A participação no capital social não se dá pelo valor subscrito, mas, sim, pelo efetivado através da integralização (...)."

Por este mesmo motivo é que também é possível se efetuar nesse caso a exclusão extrajudicial do sócio majoritário. Ora, nada impede que os sócios minoritários optem por

${ }^{20}$ LOPES, Idevan César Rauen. Empresa \& Exclusão do Sócio, 2a Ed. Curitiba, Juruá, 2008, p.130. 
excluir extrajudicialmente o sócio que subscreveu a maioria das quotas, mas não as integralizou.

Porém, se o sócio for parcialmente remisso, ou seja, tiver integralizado montante do capital social, deve-se proceder á averiguação do montante integralizado pelo sócio, pois este entrará na conta para a obtenção do qorum da exclusão. Neste caso, se o capital subscrito pelo sócio já for maior do que o dos demais sócios, só poderão estes pleitear sua saída pela via judicial.

\subsection{Exclusão na Sociedade composta por dois Sócios}

Antes da entrada em vigor do no Código Civil de 2002, a exclusão de sócio na sociedades compostas por apenas dois sócios, era criticada por larga doutrina, embora encontrasse defensores como ilustríssimo professor Fábio Konder Comparato ${ }^{21}$ :

“Finalmente, acho que não há dúvida alguma quanto à possibilidade teórica da exclusão do sócio nas sociedades com dois sócios apenas. Como já mostrei, três sistemas jurídicos aceitaram essa solução e ela corresponde a uma necessidade."

Apesar de ausência de previsão legal específica, os defensores da exclusão do sócio nesta hipótese se apoiavam na possível ampliação da interpretação do art. 206, I, "d", da Lei 6.404/76 para os demais tipos societários. Tal legislação traz a seguinte redação:

“Art. 206 - Dissolve-se a companhia: I - de pleno direito: (...) d) pela existência de 1 (um) único acionista, verificada em assembleia-geral ordinária, se o mínimo de 2 (dois) não for reconstituído até à do ano seguinte, ressalvado o disposto do art. 251."

Ora, já antes mesmo da legislação civil corrente entrar em vigor parecia correto se admitir o direito de exclusão do sócio na sociedade formada por apenas dois sócios. Não parece correto, havendo um sócio detentor da maioria absoluta das quotas representativas do capital social, que este tenha que ingressar em juízo para ver excluído o sócio que esteja pondo em risco a continuidade dos negócios sociais.

\footnotetext{
${ }^{21}$ COMPARATO, Fábio Konder. Exclusão de Sócio nas Sociedades de Responsabilidade Limitada. Revista de Direito Mercantil. São Paulo, n. 25, 1977, 1977, p. 52.
} 
É claro que para a regular manutenção da sociedade se exigirá que o mínimo de dois sócios seja recomposto dentro do prazo legal acima mencionado, sob pena de dissolução da sociedade.

Com a entrada em vigor do Código Civil de 2002, a questão parece ter sido clarificada. É que ao tratar da dissolução das sociedades comerciais, o legislador editou o art. 1.033, IV, verbis:

“Art. 1.033. Dissolve-se a sociedade quando ocorrer: (...) IV - a falta de pluralidade de sócios, não reconstituída no prazo de cento e oitenta dias."

Tal dispositivo, conjugado com o art. 1.087, CC, foi determinante para a resolução do impasse. Pode o sócio. na sociedade limitada composta por dois sócios, excluir o outro, ficando como único sócio pelo prazo legal. Pode ainda, plea legislação corrente, transformar a sociedade em firma individual, desde que esta tenha os requisitos para tal, sem recorrer ao judiciário.

Não obstante o discorrido sobre o tema, é corriqueiro nos dias atuais deparar-se com sociedades limitadas compostas por dois sócios que detêm exatos cinquenta por cento do capital cada um.

Neste caso, se entende impossível conseguir-se a exclusão extrajudicial do sócio, uma vez que jamais se alcançará o quorum de maioria absoluta necessário para instalar a assembleia ou reunião para este fim, restando aos sócios a via do Poder Judiciário para requerer a exclusão.

\subsection{Procedimento Judicial da Exclusão do Sócio}

Esgotadas as possibilidades de exclusão do sócio em sede administrativa, passamos então a analisar as hipóteses em que pode o sócio ser excluído através de interpelação judicial.

É que, como veremos, o procedimento extrajudicial, por mais vantajoso que seja para a sociedade e para os demais sócios, não engloba todas as possibilidades previstas em lei para a exclusão do sócio da sociedade comercial, notadamente a exclusão do sócio majoritário. 
A exclusão judicial do sócio é procedimento moroso e nem sempre bem sucedido, causando graves consequências para a sociedade, motivo pelo qual a doutrina aconselha que tal procedimento seja invocado apenas como último recurso, para a resolução dos conflitos na sociedade.

\subsubsection{Exclusão de Sócio Majoritário por Falta Grave}

Inicialmente, cumpre análise detalhada sobre o procedimento de exclusão judicial do sócio majoritário. Como explicado no item 3.1.2 acima, o único meio de se determinar a exclusão do sócio majoritário de uma sociedade limitada é a via judicial (exceção feita ao sócio remisso, constante no item 3.2 acima), pois em sede administrativa jamais se chegaria ao quorum necessário para se deliberar sua exclusão.

Neste sentido é claro que não há óbice algum quanto à exclusão judicial do sócio minoritário, se assim preferir a maioria. No entanto, parece certo que tal hipótese seja inócua, tendo em vista que o sócio minoritário pode ser excluído extrajudicialmente, de forma mais simples e eficaz.

O art. 1.030 do CC trouxe a seguinte redação, regulando esta modalidade de exclusão:

“Art. 1.030. Ressalvado o disposto no art. 1.004 e seu parágrafo único, pode o sócio ser excluído judicialmente, mediante iniciativa da maioria dos demais sócios, por falta grave no cumprimento de suas obrigações, ou, ainda, por incapacidade superveniente."

A incapacidade superveniente será estudada com mais ênfase nos itens que se seguem. O que sustenta o procedimento judicial do art. 1.030, segundo massiva doutrina, é a "falta grave" cometida pelo do sócio excluendo, remetendo-nos ao conceito de "justa causa". A idéia do legislador foi simples: tentar garantir ao sócio minoritário uma via de expulsar sócio majoritário que esteja pondo em risco a continuidade dos negócios sociais.

Na verdade, como já mencionado, o direito de excluir o sócio não pertence ao sócio minoritário ou ao majoritário, mas sim à sociedade. Por isso, deverá a empresa ingressar com a ação para a exclusão do sócio faltoso. 
Para tanto, a maioria absoluta dos sócios deverá propor a ação representando a pessoa jurídica. É evidente que para a verificação desse quorum não se deve levar em consideração a participação social do sócio a quem se pretende excluir, pois caso contrário tal quorum se tornaria inatingível.

Caberá ao Judiciário analisar no caso concreto as alegações das partes e chegar a uma decisão sobre a exclusão. Nota-se que nesse caso a exclusão sempre se dará por sentença judicial.

Na teoria, portanto, é possível ter-se a exclusão judicial do sócio majoritário. No entanto excluir o sócio majoritário na prática pode ser complicado, pois a sociedade pode não suportar, por exemplo, o crédito que será criado em favor do sócio excluído contra a sociedade em razão de sua exclusão.

Ou seja, a função do magistrado nesse caso é bem mais complexa do que simplesmente verificar se a conduta do sócio majoritário é suficiente para se configurar a exclusão. Como o que se quer proteger é a continuidade da empresa, o juiz deve analisar se a mesma terá condições se suportar a saída do sócio majoritário e continuar em atividade para determinar sua exclusão.

\subsubsection{Exclusão de Sócio por Incapacidade Superveniente}

Outra situação de exclusão que prescinde da análise do Judiciário é a exclusão do sócio por capacidade superveniente, que encontra previsão no já mencionado art. 1.030 do Código Civil. Neste cenário, o sócio perfeitamente capaz por algum motivo superveniente perde sua capacidade, devendo ser excluído pela sociedade.

No caso da sociedade limitada, é comum se deparar com o posicionamento de que, contanto que o capital tenha sido integralizado, não haveria motivos para se excluir o sócio por sua incapacidade superveniente, uma vez que suas decisões na vida social poderiam ser tomadas por um curador que enquanto administrador dos bens daquele sócio. 
No entanto, esse posicionamento não parece certo, uma vez que pode haver decisões dentro da via de empresa que dificultem a atuação do curardor, como, por exemplo, uma sociedade comercial de pequeno porte que, em face de sucessos em seus negócios, visa ampliá-los mediante contração de empréstimo bancário. Deve o curador nesse caso aprovar o endividamento da sociedade com o risco de comprometer o patrimônio do sócio que tornou-se incapaz? Nesse sentido, teria o curador poderes para tanto?

Sem dúvida são questões controversas, e parece que a decisão mais acertada seria o afastamento do sócio, obviamente mediante apuração de seus haveres e pagando-lhe o devido por sua participação societária.

Por ser tema controvertido, pareceu acertar o legislador em remeter a questão ao crivo do Judiciário, que deverá decidir no caso concreto pelo afastamento ou não do sócio, sempre tendo em vista o melhor interesse da sociedade.

Cabe ainda analisar que há posicionamento doutrinário no sentido de considerar a incapacidade latu sensu e a incapacidade stritu sensu para se determinar a exclusão do sócio.

$\mathrm{Na}$ incapacidade latu sensu, o que se verifica é a incapacidade genérica do sócio, que não está mais apto a tomar decisões formais por si só, enquanto na incapacidade stritu sensu o que se verifica é a perda da condição especifica do sócio necessária para exercer suas funções sociais.

Nesse sentido, anota Eduardo Goulart Pimenta ${ }^{22}$ :

"Quando a realização do objeto social depender de determinada condição pessoal dos sócios e algum(ns) dele(s) tiver retirado o poder de realizar tal conduta, há que se entender como ocorrida a hipótese de exclusão ora tratada. É, por exemplo, o caso da sociedade constituída por médicos, para a prática de medicina, em que um dos membros tem cassada sua licença profissional, Este sócio, em virtude da sanção sofrida, impedido de colaborar com os demais (ao menos de forma plena) na realização da atividade comum."

Parece acertada a posição do doutrinador: não pode se manter na sociedade o sócio que teve cassada a condição específica pela qual exercia papel fundamental para consecução dos negócios sociais, pois não poderá contribuir para coma sociedade de forma plena.

\footnotetext{
${ }^{22}$ PIMENTA, Eduardo Goulart. Exclusão e Retirada de sócios: conflitos societários e apuração de haveres no Código Civil e na Lei das Sociedades Anônimas - Belo Horizonte: Mandamentos, 2004.
} 


\subsubsection{Exclusão do Sócio Falido}

Outra possibilidade de exclusão de sócio trazida pelo Código Civil foi a figura do sócio, pessoa jurídica, que tendo sua falência decretada não pode mais fazer parte da sociedade.

Assim estabeleceu o legislador no parágrafo único do art. 1.030:

“Parágrafo único. Será de pleno direito excluído o sócio declarado falido, ou aquele cuja quota tenha sido liquidada nos termos do parágrafo único do art. 1.026."

O legislador foi especialmente feliz em incluir tal previsão na legislação civil em vigor o dispositivo. Isso porque a sua participação do sócio falido na sociedade será arrecadada pela Administrador Judicial a fim de efetuar o pagamento dos credores do falido.

Tal previsão permite, que, antes que o Administrador Judicial faça a arrecadação, a sociedade efetuar a exclusão do sócio, apurando seus haveres, que então serão entregues ao Administrador Judicial.

Há o entendimento de que deve-se equiparar à figura da pessoa jurídica falida o insolvente civil. Isso porque, a pessoa física que tem a insolvência civil decretada, por esse motivo ficaria impossibilitada de participar da sociedade, tendo seu patrimônio comprometido pelo pagamento de credores. De fato, a analogia parece apropriada, ainda que não haja previsão especifica do insolvente na esfera civil ser excluído da sociedade.

Tal modalidade difere das demais formas de exclusão judicial por um simples motivo: a exclusão em si não se dá de forma judicial, mas de pleno direito.

O caráter judicial deste tipo de exclusão se dá na necessidade de decretação judicial de falência ou insolvência para que seja efetuada a exclusão de pleno direito. Ou seja, neste caso deve a sociedade aguardar a decisão judicial e, uma vez decretada a falência, efetuar a exclusão extrajudicialmente.

Como a exclusão se dá de pleno direito, fica dispensada a realização de assembléia ou de reunião de sócios para que seja decretada a exclusão. 


\subsubsection{Exclusão por Quota Penhorada}

Sempre houve a discussão doutrinária acerca da possibilidade de efetuar-se penhora de quotas de sócios em razão de suas dívidas particulares. Antes da entrada em vigor do Código Civil de 2002, admitia-se essa possibilidade ao se tratar de sociedade de capital, vedando-se na sociedade de pessoas.

A jurisprudência, em outro sentido, permitia a penhora da quota em qualquer situação sendo facultado ao comprador pedir a dissolução parcial da sociedade caso os sócios não concordassem com seu ingresso na sociedade.

O diploma civil que entrou em vigor em 2002 consagrou a possibilidade de que as quotas sejam penhoradas e liquidadas. Nesse caso, o sócio que figura no pólo passivo de uma execução judicial, terá suas quotas levadas a leilão, podendo o comprador pedir a liquidação da quota à sociedade, em face de seu valor patrimonial.

Deste modo, uma vez penhorada em processo de execução as quotas do devedor, este perde sua qualidade de sócio, pois o valor patrimonial da quota é perdido, não fazendo sentido sua permanência na empresa.

O procedimento a ser tomado é simples: após a liquidação da quota, deverá ser promovida uma alteração contratual homologando a saída do sócio. 


\section{CAPÍTULO IV - APURAÇÃO DE HAVERES}

Uma vez excluído o sócio, resta a este exercer o direito que ainda ostenta com a condição sócio, de caráter estritamente patrimonial, seja esta a apuração de seus haveres para que seja devidamente indenizado pela sua participação societária, de modo a reduzir ao máximo os danos trazidos àquele sócio pela exclusão.

Tal situação tem a maior importância para o procedimento da exclusão do sócio, especialmente ao se tratar de exclusão extrajudicial, pois uma apuração de haveres preparada com precisão pode evitar o ingresso judicial do sócio excluído para que sejam discutidos os valores.

O procedimento da apuração de haveres tem previsão legal no encontrada no art. 1.031 de Código Civil, tendo seu caput a seguinte redação:

“Art. 1.031. Nos casos em que a sociedade se resolver em relação a um sócio, o valor da sua quota, considerada pelo montante efetivamente realizado, liquidar-se-á, salvo disposição contratual em contrário, com base na situação patrimonial da sociedade, à data da resolução, verificada em balanço especialmente levantado."

Observando-se a letra da lei, a apuração dos haveres do sócio excluído deverá ser feita através de um balanço especial, no qual um processo técnico contábil definirá o valor total do patrimônio da sociedade no momento em que houve a exclusão do sócio.

No patrimônio da empresa deverão ser considerados os bens corpóreos e incorpóreos da empresa, e busca-se apurar o valor de mercado da empresa, pelo qual se pode definir de forma adequada o quantum devido ao sócio excluído.

No caso em tela, como anota com precisão o doutrinador Fábio Ulhôa Coelho ${ }^{23}$ o que se faz é uma simulação da dissolução total da sociedade, ou seja, o objetivo é determinar-se quanto seria devido àquele sócio se esta cessasse suas atividades por completo. Nas palavras do doutrinador, lê-se:

\footnotetext{
${ }^{23}$ COELHO, Fábio Ulhoa, A sociedade limitada no novo Código Civil. São Paulo, Saraiva, 2003, p. 160.
} 
“A apuração de haveres, em outras palavras, é a simulação da dissolução parcial da sociedade. Por meio de levantamento contábil, que reavalia, a valor de mercado, os bens corpóreos e incorpóreos do patrimônio social, e da consideração do passivo da sociedade, projeta-se o quanto seria o acervo remanescente caso a sociedade limitada fosse, no momento, dissolvida".

Atenta-se, como bem ressalta o doutrinador, que o objetivo é que o sócio excluído não obtenha valor diferente (para mais, ou para menos) do que the seria devido no caso de partilha, na dissolução total da sociedade.

Vale lembrar que no caso específico da apuração de haveres na exclusão de sócio é muito difícil que as partes satisfeitas, pois estão em lados diametralmente opostos: enquanto os sócios remanescentes querem que a avaliação seja feita de modo a pagar o mínimo possível ao sócio excluído, este deseja elevar o quanto possível seu crédito contra a sociedade.

Na realidade o sócio, uma vez excluído tem muito pouca ingerência sobre a forma que será feita o balanço especial, que será preparado por empresa indicada pelos sócios remanescentes.

Por isso, não é incomum verificar o ingresso judicial do sócio excluído para pleitear majoração dos valores apurados face sua exclusão, sempre pleiteando a majoração de valores que tenham sido apurados pelos sócios remanescentes. Por isso, sempre deve se observar, por parte da maioria que delibera a exclusão, que tal apuração seja feita com o cuidadosamente, justamente para evitar o ingresso judicial do sócio retirante.

Em atenção ao parágrafo segundo do art. 1.031, o pagamento do reembolso ao sócio excluído deverá ser feito em dinheiro no prazo de noventa dias uma vez consolidada a exclusão. No entanto, cabe notar que a lei abriu a possibilidade do contrato social dispor de maneira diferente, caso no qual deverão ser observadas as previsões contratuais.

Cabe ainda comentário sobre uma divergência doutrinária que paira sobre os lucros do exercício em que se efetuou a exclusão. Serão devidos ao sócio excluído os dividendos do exercício ainda corrente à época de sua exclusão?

Ora, parece que neste caso a discussão não tem motivo para prosperar. Isso porque, mesmo que se chega à conclusão de que não é não devem se restituídos os dividendos ao sócio 
excluído, tal importância estaria incluída do ativo da sociedade, ativo este que será avaliado e fará parte da apuração dos haveres a qual determinará o quantum devido ao sócio retirante. 


\section{CONCLUSÃO}

O trabalho apresentado teve como objetivo analisar o procedimento da exclusão de sócios como um todo, dando ênfase em sua previsão no Código Civil de 2002.

Através de larga pesquisa doutrinária, buscou-se chegar às melhores conclusões sobre os diversos pontos controversos do tema, visando sempre um posicionamento não tendencioso e imparcial, para o qual foram analisados autores classicamente defensores da minoria, tanto como autores pró-majoritário.

A primeira conclusão, ainda obtida em caráter preliminar, foi sobre a crescente importância do instituto da exclusão de sócios para a preservação da empresa moderna. Como visto em todo o trabalho, é vital que se encontre neste instituto a ferramenta necessária para consertar uma engrenagem deficiente, sem que se tenha que desmontar todo o aparelho.

Avançando nos estudos, talvez um dos aspectos mais relevantes deste trabalho seja a demonstração, corroborada por contemporânea e relevante doutrina, do declínio do conceito de affectio societatis por sua imprecisão e impossibilidade de com ele se clarificar quais casos seriam passíveis de exclusão, possibilitando a exclusão arbitrária.

Nesse prisma, acolheu-se a posição da doutrina que sugere sua substituição pelo conceito de fim social, que confere maior clareza no momento de se verificar quais atos seriam passíveis de exclusão do sócio.

No tocante ao procedimento da exclusão, esse se dividiu nas vias judicial e extrajudicial, as quais foram amplamente estudadas e explicitadas. Foi possível concluir, desta forma que a exclusão é um procedimento que apesar de não gozar de regulamentação mais extensa, é passível de uma padronização para aumentar a segurança jurídica, definindo-se cada vez em quais hipóteses o sócio poderia ser excluído.

Na solução extrajudicial, pareceu correta a tese de que podem os sócios, mediante deliberação da maioria do capital social excluir o sócio minoritário sempre tendo a justa causa como cláusula potestativa. Nesse ponto, chegamos à conclusão de que o simples desentendimento entre os sócios não é motivo suficiente para a exclusão do sócio da 
sociedade. É mais do que comum, na seara do mundo dos negócios, que sócios possam vir a ter desentendimentos, mas parece que esta situação é normal e corriqueira, tal qual uma simples discussão não seria suficiente para determinar a dissolução de um matrimônio.

Numa situação extrema, no entanto, onde o sócio minoritário esteja trazendo prejuízos diretos ou indiretos para a sociedade, deve prevalecer o poder da maioria, sempre em vista da manutenção da empresa, e sob este fundamento efetuar-se a exclusão, independente de homologação pelo poder Judiciário.

Ainda sobre a exclusão extrajudicial, analisou-se o direito de defesa do sócio excluendo, chegando-se à conclusão de que esse direito não seria fundamental, uma vez que, sendo o ato de exclusão tão sério, os sócios já efetuam cuidadosa análise antes de convocar a assembléia cujo fim especial é deliberar sobra a exclusão.

Ademias, estudamos os casos de exclusão judicial, na qual obrigatoriamente é necessário recorrer-se ao Poder Judiciário para obter a exclusão, ou ao menos para uma fase preliminar ao procedimento. Neste sentido, parece de maior relevância a possibilidade a possibilidade da exclusão do sócio majoritário por falta grave, que estaria colocando em risco a continuidade da sociedade.

No entanto, verificou-se que neste caso o magistrado deve atuar com prudência, primeiramente analisando os motivos que levaram os minoritários a pleitearem a exclusão do sócio e, mais importante, se a sociedade tem condições materiais de, na prática, sobreviver à exclusão do sócio majoritário, o que nem sempre é possível.

Num balanço geral chagamos as conclusões de que (i) o instituto da exclusão do sócio vêm assumindo relevante papel no direito empresarial moderno, sendo uma forma de defesa da sociedade contra um mal interno que põe em risco seu funcionamento, (ii) o conceito de affectio societatis é impreciso e insuficiente, devendo ser substituído pelo conceito de fim social a fim de gerar mais segurança jurídica ao procedimento da exclusão de sócio e (iii) os procedimento judicial e extrajudicial encontram amparo legal suficiente, tendo sido aceitos pela doutrina e jurisprudência, sendo as ferramentas necessárias para a implementação prática do instituto. 
Como mencionado no início da obra, o que se sugere, através das críticas e problemas encontrados no procedimento recente, é que haja uma padronização da aplicação do instituto, dessa clarificando as hipóteses passíveis de exclusão. 


\section{BIBLIOGRAFIA}

COMPARATO, Fábio Konder. Exclusão de Sócio nas Sociedades de Responsabilidade Limitada. Revista de Direito Mercantil. São Paulo, n. 25, 1977.

FILHO, Celso Barbi. Dissolução Parcial de Sociedades Limitadas. Belo Horizonte: Mandamentos, 2004.

LUCENA, José Waldecy. Das Sociedades Limitadas. 6.ed. Rio de Janeiro. Renovar, 2005.

NUNES, A. J. Avelãs. O Direito de Exclusão dos Sócios nas Sociedades Comerciais. São Paulo, Cultural Paulistana, 2001.

FONSECA, Priscila M.P. Corrêa da. Dissolução Parcial, Retirada e Exclusão se Sócio. São Paulo, Atlas, 2002, p. 39.

NOVAES E FRANÇA, Erasmo Valladão Azevedo e; ADAMEK, Marcelo Vieira, "Affectio Societatis: um conceito Jurídico Superado no Moderno Direito Societário pelo Conceito de Fim Social", Revista de Direito Mercantil, industrial econômico e financeiro, São Paulo, Melhoramentos, vol. 149/150, jan./dez. 2008

WALD, Arnoldo, Comentários ao Novo Código Civil, v. XVI, t. II, Rio de Janeiro: Forense, 2005, p. 235.

CARVALHOSA, Modesto, Comentários ao Código Civil: parte especial: do direito de empresa (arts. 1.052 a 1.195), vol. 13, São Paulo, Saraiva, 2003.

GONÇALVES NETO, Alfredo de Assis, Lições de direito societário, 2a ed., São Paulo, Juarez de Oliveira, 2004.

LOPES, Idevan César Rauen. Empresa \& Exclusão do Sócio, 2ª Ed. Curitiba, Juruá, 2008. 
PIMENTA, Eduardo Goulart. Exclusão e Retirada de sócios: conflitos societários e apuração de haveres no Código Civil e na Lei das Sociedades Anônimas - Belo Horizonte: Mandamentos, 2004.

FAZZIO JÚNIOR, WALDO. Sociedades Limitadas: de acordo com o Código Civil de 2002. 2. Ed. São Paulo: Atlas, 2007.

COELHO, Fábio Ulhoa, A sociedade limitada no novo Código Civil. São Paulo, Saraiva, 2003. 